Biogeography of the Southern End of the World 


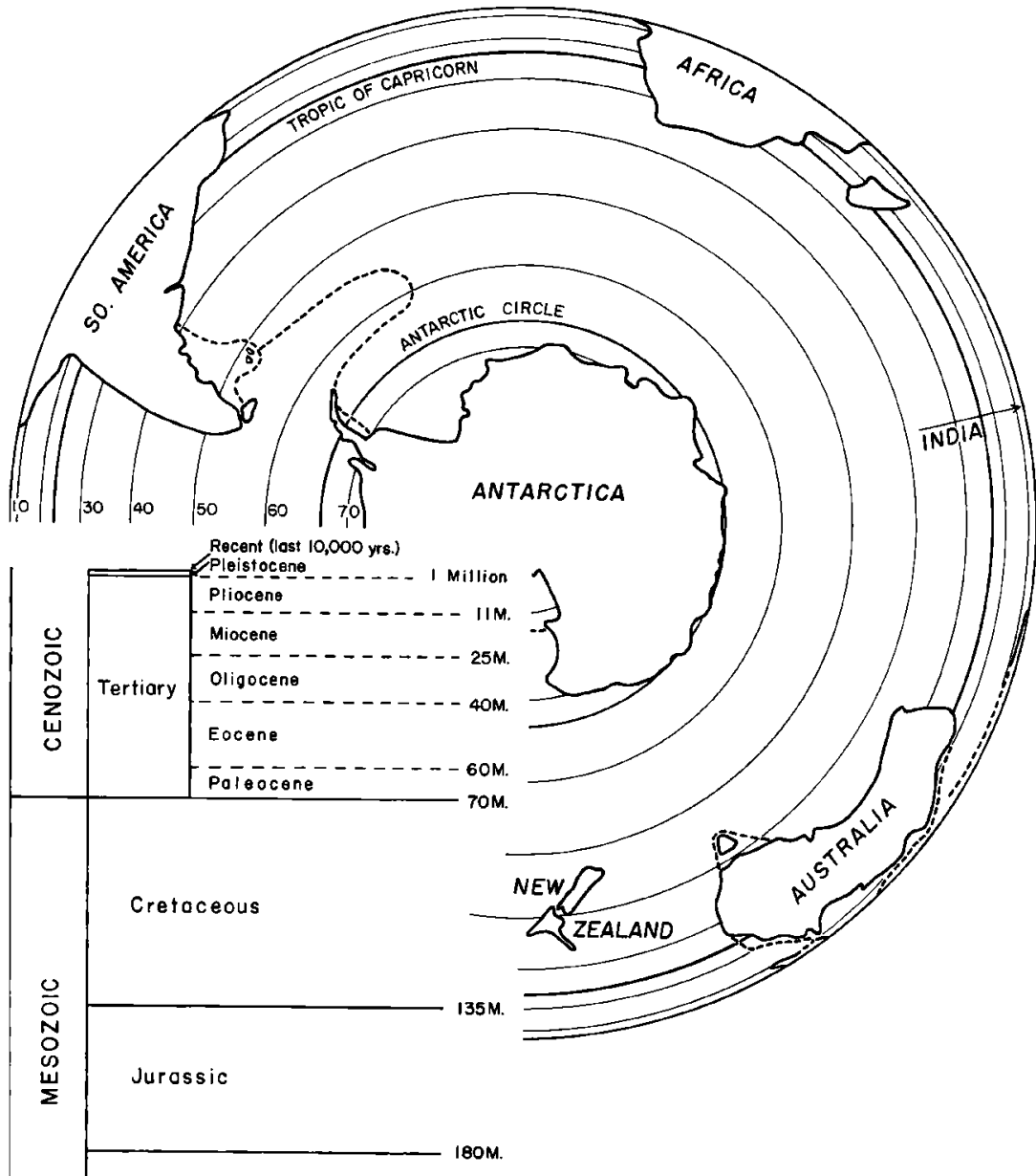

The southern end of the world (orthographic projection) with geologic time scale (intervals after Kummel 1961:20, 225 M. Fig. 1-5).

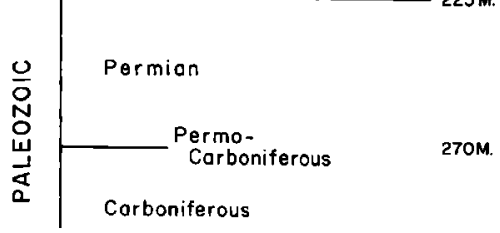




\section{Biogeography of}

\section{the Southern End}

of the World

Distribution and history of far-southern life and land, with an assessment of continental drift

\section{PHILIP J. DARLINGTON, Jr.}

Museum of Comparative Zoology, Harvard University

HARVARD UNIVERSITY PRESS

Cambridge, Massachusetts $\cdot 1965$ 
(C) Copyright 1965 by the President and Fellows of Harvard College

All rights reserved

Distributed in Great Britain by Oxford University Press, London

Library of Congress Catalog Card Number 65-16681

Printed in the United States of America 